\title{
nature
}

14 June 2001 Volume 411 Issue no 6839

\section{Towards new standards in university-industry collaboration}

A new report provides a useful overview of issues surrounding the mutual and conflicting interests of academic researchers and business. Its recommendations should inspire caution rather than unalloyed enthusiasm.

“I fyou had time to patent it, it must be obsolete." That is one of the more memorable quotes from an important new survey of the issues arising from collaborations between US companies and universities. It reflects an ever-quickening world in which academic-industrial collaboration is the norm rather than, as some university administrators and company heads of research and development reportedly still see it, a questionable exception or even an aberration. On the contrary, $10 \%$ of all US academic funds now come from industry, and the money is growing.

The report was published last week by the Business-Higher Education Forum (see page 728), a partnership between the American Council on Education and the National Alliance of Business. It usefully highlights the need for universities to streamline their support and responsiveness in developing new collaborations - though not at the expense of quality control and protection of the university's core responsibilities. The information-technology (IT) sector especially, to which the above quote refers, is quick to exit when it encounters bureaucratic delays. The report is co-signed not only by the heads of top-quality research universities but also by the chief executives of major pharmaceutical and IT companies. It urges companies to give top-down backing for collaborations, so as to minimize obstacles from internal research groups protecting their turf.

The need for transparency and for the disclosure of conflicting financial interests and commitments have been called for often enough before, and receive due support here. Less often discussed are the troublesome issues of 'background rights', where a university is pressured to allow a collaborating company rights to technologies arising from university projects sponsored by others, including the federal government, in order to give the company the full value of the core inventions. Here the report aptly concedes that there is no easy answer. But it does not mention occasions when a company puts pressure on a university that can ill afford the heavy-duty legal work to explore the ramifications.

There are long-established concerns about publication delays while a company examines a discovery's commercial potential. And the report points to increasing pressures by industry to lengthen delays beyond three months. Valuably, it states that 60-90 days should be enough for most companies to express an interest and register for a patent - which, in the United States, leaves the way clear for publication.

The report is also helpful in pointing the way forward on research costs. It shows that there is no excuse for universities to succumb to pressures from companies and their own faculty to provide subsidized research to industry. It urges that universities charge federal rates for indirect costs.

In one key controversial area the report gives little help. It reiterates the well-known problems that arise when researchers develop materials and techniques that they want to patent or exploit, while the collaborating company may want to see those techniques widely used. But the report provides no recommendations.

There is also one major gap. The report says little about regulating and overseeing collaborations, or about public consultations concerning best practice. No one would suggest that there should be a central regulator - the main pressure for good behaviour comes from the conditions of funding set by agencies such as the National Institutes of Health, which can be powerful; but they cannot adequately protect the wider public interest in preserving universities' fundamental roles.

The report is welcome for what it is: the well-considered views of those with a vested interest in making such collaborations acceptable. It highlights occasions when companies have shown enlightened attitudes towards universities. And it represents good guidance. But it does not add up to a framework for resisting strong companies that take a predatory approach to academic collaboration.

\section{An appropriate apology}

The president of the Max Planck Society has struck the right note in acknowledging past crimes against humanity.

$\mathrm{t}$ $\mathrm{t}$ is wrong to dwell incessantly on the excesses of an increasingly distant past. Yet awareness of its past continues to haunt discussions in Germany about modern biology, particularly stem-cell techniques. And a history of barbaric science willingly carried out under tyranny may be all too relevant elsewhere today and in the future. So a statement last week by the head of Germany's most prestigious scientific institution deserves widespread attention.

Hubert Markl's thoughtful apology (see page 726) for the violations of human dignity perpetrated by scientists of the Kaiser Wilhelm Society, which was dissolved after the Second World War and re-established as the Max Planck Society (MPS), was well expressed. Avoiding self-serving rhetoric, he reflected that no one has the right to seek forgiveness, or alleviation of guilt, for "inextinguishable shame"; they can only express recognition of responsibility, and regret. In his speech to science historians and survivors of Josef Mengele's experiments in Auschwitz, Markl expressed a truth that Germans often flinch from articulating: that Germany was not the first and, tragically, not the last to develop an inhuman, racist regime that used genocide as a political instrument.

When his presidency of the MPS ends next year, Markl can take pride in his achievement of having opened up not just the archives of the MPS to independent historians, but also a better-informed debate on how German scientists can appropriately reflect on the Nazi past while embracing a confident future. 